\title{
Electron Donor Systems to Facilitate Development of Assays for Two Flavoproteins Involved in Tetrahydromethanopterin Biosynthesis
}

\author{
Chao Pang, Jose Moscaira, Jenny Gong, Madeline E. Rasche \\ Department of Chemistry and Biochemistry, California State University at Fullerton, Fullerton, CA, USA \\ Email: merasche@fullerton.edu
}

How to cite this paper: Pang, C., Moscaira, J., Gong, J. and Rasche, M.E. (2020) Electron Donor Systems to Facilitate Development of Assays for Two Flavoproteins Involved in Tetrahydromethanopterin Biosynthesis. Advances in Microbiology, 10, 275-294.

https://doi.org/10.4236/aim.2020.106020

Received: March 31, 2020

Accepted: June 25, 2020

Published: June 28, 2020

Copyright $\odot 2020$ by author(s) and Scientific Research Publishing Inc. This work is licensed under the Creative Commons Attribution International License (CC BY 4.0).

http://creativecommons.org/licenses/by/4.0/

\begin{abstract}
Methane production by archaea depends on tetrahydromethanopterin $\left(\mathrm{H}_{4} \mathrm{MPT}\right)$, a pterin-containing cofactor that carries one-carbon units. Two redox reactions within the nine steps of $\mathrm{H}_{4} \mathrm{MPT}$ side chain biosynthesis have been hypothesized. Biochemical assays have demonstrated that the archaeal iron-sulfur flavoprotein dihydromethanopterin reductase $\mathrm{X}(\mathrm{DmrX}$ or MM1854) catalyzes the final reaction of the pathway, the reduction of dihydromethanopterin to $\mathrm{H}_{4} \mathrm{MPT}$, using dithiothreitol (DTT) as an artificial electron donor. The crystal structure of DmrB, a bacterial DmrX homolog that lacks iron-sulfur clusters, has led to a proposed ping-pong mechanism of electron transfer between $\mathrm{FMNH}_{2}$ and the FMN prosthetic group of DmrB. However, an enzymatic assay to test the hypothetical DmrB mechanism is lacking because a suitable electron donor has not previously been identified. Furthermore, a second uncharacterized archaeal flavoprotein (MM1853) has been hypothesized to function in $\mathrm{H}_{4} \mathrm{MPT}$ side chain biosynthesis. In this work, to facilitate the development of assays to elucidate the functions of DmrB and MM1853, we tested a variety of electron donors, including dithiothreitol, ferredoxin, and a system consisting of NADH and an NADH-dependent flavin-reducing enzyme (Fre). Reduction of the DmrB prosthetic group (FMN) was measured as a decrease in absorbance at $460 \mathrm{~nm}$. NADPH, NADH, and DTT were unable to reduce DmrB. However, NADH/Fre was able to reduce DmrB within $70 \mathrm{~min}$ (initial rate of $1.3 \mu \mathrm{M} / \mathrm{min}$ ), providing the basis for a future DmrB activity assay. Carbon monoxide (CO)/CO dehydrogenase/ferredoxin reduced DmrB more rapidly within $6 \mathrm{~min}$. Both electron transfer systems reduced a second flavin-containing archaeal protein MM1853, which is predicted to catalyze the third step of $\mathrm{H}_{4}$ MPT biosynthe-
\end{abstract}


sis. While NADH and NADPH were incapable of directly reducing the FMN cofactor of MM1853, DTT or NADH/Fre could eliminate the FMN peaks. These results establish the basis for new oxidoreductase assays that will facilitate testing several proposed DmrB mechanisms and defining the specific function of MM1853 in methanogen cofactor biosynthesis.

\section{Keywords}

Methanopterin, Coenzyme Biosynthesis, Dihydromethanopterin Reductase, Flavoprotein, Archaea, Methanogenesis

\section{Introduction}

Methane-producing microorganisms (methanogenic archaea) require strictly anaerobic conditions for growth and are considered extremophiles due to their inability to grow in the presence of $\mathrm{O}_{2}$ [1]. Methane production by archaea depends on tetrahydromethanopterin $\left(\mathrm{H}_{4} \mathrm{MPT}\right)$, an unusual pterin-containing cofactor that carries one-carbon units [2]. Chemical compounds that block a committed step in $\mathrm{H}_{4} \mathrm{MPT}$ biosynthesis have been shown to inhibit the microbial production of methane, a greenhouse gas associated with climate change [3] [4] [5]. In addition, because methane-producing microbes in the intestinal tracts of rodents and humans have been correlated with obesity [6], newly discovered enzymes in the pathway of $\mathrm{H}_{4} \mathrm{MPT}$ biosynthesis could serve as potential targets for novel pharmaceutical drugs intended to treat morbid obesity.

Of the nine enzymatic steps in the pathway for synthesis of the $\mathrm{H}_{4} \mathrm{MPT}$ side chain, only the last step and the third step are proposed to be oxidation-reduction reactions [7] [8]. Genetic complementation studies [9] and biochemical assays [10] have together demonstrated that the final reaction of $\mathrm{H}_{4} \mathrm{MPT}$ side chain biosynthesis (step 9) is catalyzed by an archaeal flavoprotein A (AfpA) that is also called dihydromethanopterin reductase $\mathrm{X}$ (DmrX or MM1854) (Figure 1(a)). In addition to containing a binding site for FMN, the DmrX sequence contains two binding sites for four-iron four-sulfur (4Fe-4S) centers [11], which are associated with the ability of dithiothreitol (DTT) to serve as an artificial electron donor [10]. The third step of $\mathrm{H}_{4} \mathrm{MPT}$ side chain biosynthesis is also a putative oxidation-reduction step [7], but the enzyme catalyzing this reaction has not yet been discovered.

Although DmrX is a strong candidate as a target for inhibiting methane production by methanogenic archaea, detailed structural and mechanistic studies of DmrX have been hindered by the presence of the two $4 \mathrm{Fe}-4 \mathrm{~S}$ clusters that make DmrX susceptible to inactivation by $\mathrm{O}_{2}[10]$. However, a DmrX homolog from the aerobic bacterium Burkholderia xenovorans $(\mathrm{DmrB})$ has been identified that can serve as an oxygen-stable model system for flavin-dependent dihydromethanopterin reductases. The air-stable DmrB protein lacks $4 \mathrm{Fe}-4 \mathrm{~S}$ cluster bind- 
ing sites and yet retains one FMN binding site per monomer [9]. Curiously, a crystal structure for DmrB has been reported that shows two FMN molecules per monomer rather than one [12]. This observation led the authors to propose a ping-pong mechanism of electron transfer (Figure 1(b)) in which a loosely bound $\mathrm{FMNH}_{2}$ molecule (FMN-2 $2_{\text {reduced }}$ ) transfers electrons to the tightly bound FMN prosthetic group of DmrB (FMN-1); this would be followed by the binding of the substrate dihydromethanopterin and reduction to $\mathrm{H}_{4} \mathrm{MPT}$ using electrons from reduced FMN-1 [12]. The model predicts that the loosely bound FMN-2 may be re-reduced by a flavin-reducing enzyme (Fre) with electrons from $\mathrm{NAD}(\mathrm{P}) \mathrm{H}$. This hypothetical ping-pong mechanism for DmrB electron transfer has not yet been tested biochemically, and a reductant for DmrB has not been previously reported.

A second flavoprotein, the archaeal protein MM1853 and its bacterial homolog Orf19 from Methylobacterium extorquens AM1, has also been implicated in $\mathrm{H}_{4} \mathrm{MPT}$ side chain biosynthesis. In $M$. extorquens AM1, the orfl9 gene occurs
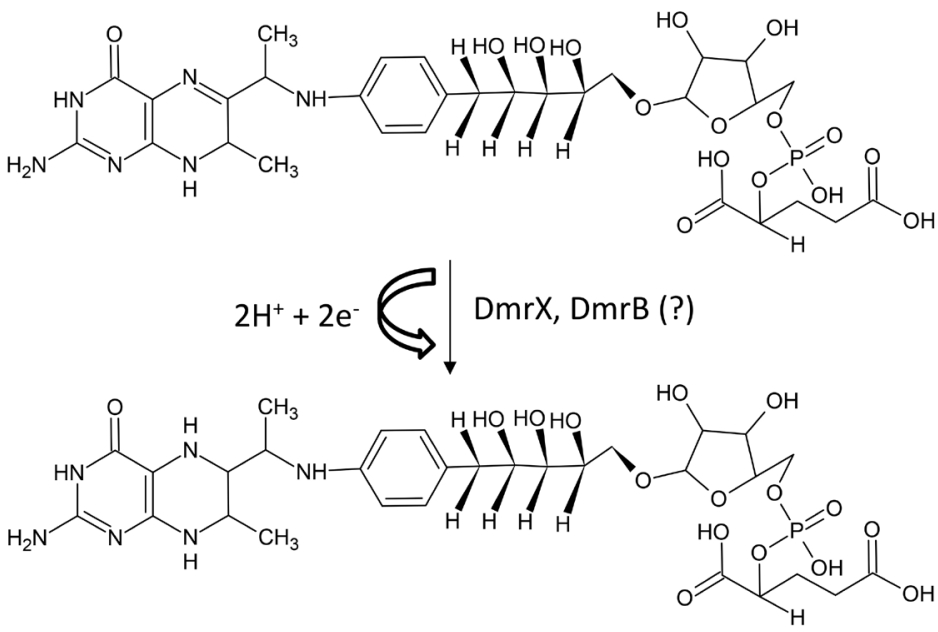

(a)

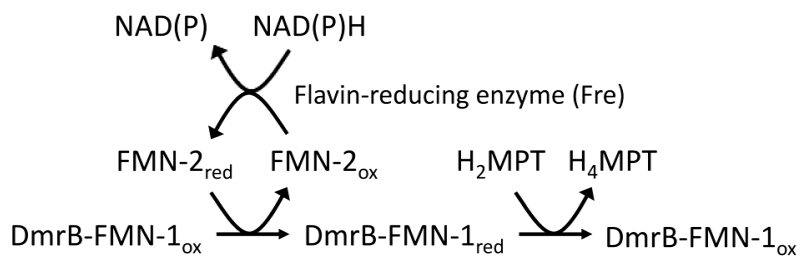

(b)

Figure 1. Reaction catalyzed by dihydromethanopterin reductase, the final step of $\mathrm{H}_{4} \mathrm{MPT}$ side chain biosynthesis. (a) The reaction of DmrX has been demonstrated previously [10]; however, a role for $\mathrm{DmrB}$ in reducing dihydromethanopterin has not yet been demonstrated biochemically. (b) In the hypothetical ping-pong mechanism for DmrB [12], NAD(P)H and flavin reducing enzyme (Fre) reduce exogenous FMN (FMN-2), which enters the active site of $\mathrm{DmrB}$ and reduces the tightly bound flavin prosthetic group (FMN-1). Subsequently, oxidized FMN-2 leaves the active site and is replaced by the proposed substrate $\mathrm{H}_{2} \mathrm{MPT}$, which accepts electrons from reduced FMN-1 and is converted to the final product $\mathrm{H}_{4} \mathrm{MPT}$. (a) Reaction of dihydromethanopterin reductase; (b) Proposed ping-pong mechanism of DmrB. 
within a cluster of $\mathrm{H}_{4} \mathrm{MPT}$-linked genes, and deletion of orf 19 eliminates the ability to the organism to synthesize $\mathrm{H}_{4} \mathrm{MPT}$ [13]. Sequence alignments have given few clues to the specific reaction catalyzed by Orf19; however, the archaeal homolog of Orf19 from the methanogen Methanosarcina mazei (MM1853, expect value $=4 \times 10^{-6}$ ) has been previously crystallized (pdb 2NR4). The two proteins share $33 \%$ identity and $50 \%$ similarity over $25 \%$ of the sequence, and the MM1853 crystal has been reported to contain one FMN bound per subunit, consistent with the activity of MM1853 as an oxidoreductase. In the M. mazei genome, the MM1853 gene resides next to gene MM1854, which codes for DmrX, a known $\mathrm{H}_{4} \mathrm{MPT}$ biosynthesis enzyme. Given the physical proximity of two genes and the presence of FMN in the MM1853 crystal structure, it is reasonable that MM1853 may catalyze an oxidoreductase reaction associated with $\mathrm{H}_{4} \mathrm{MPT}$ biosynthesis. Besides dihydromethanopterin reduction catalyzed by $\mathrm{DmrX}$, the only other known redox reaction of $\mathrm{H}_{4} \mathrm{MPT}$ side chain biosynthesis is the reductive opening of a ribose ring in the third step of the pathway [7]. It is feasible that MM1853 and Orf19 may catalyze the third reaction of $\mathrm{H}_{4} \mathrm{MPT}$ side chain biosynthesis. Therefore, identification of electron donors capable of reducing the FMN prosthetic group of MM1853 is a prerequisite for testing this hypothesis.

In this work, we have examined a variety of potential electron donors for the putative $\mathrm{H}_{4}$ MPT biosynthesis enzymes DmrB and MM1853 as a first step in developing enzymatic assays and testing the DmrB ping-pong mechanism of electron transfer.

\section{Materials and Methods}

\subsection{Media and Chemicals}

Luria-Bertani (Miller) broth (LB) was from EMD Millipore (Gibbstown, New Jersey) and purchased through Fisher Scientific (Pittsburgh, PA). DNase I and lysozyme were from Sigma Chemical Company (St. Louis, Missouri). Isopropyl $\beta$-D-1-thiogalactopyranoside (IPTG) was from UBP Bio, LLC (Aurora, CO). Protein dye-binding reagent, bovine serum albumin standard, Precision Plus Protein ${ }^{\mathrm{TM}}$ Dual Color Standards, $4 \%-15 \%$ native gels, and Bio-Safe ${ }^{\mathrm{TM}}$ Coomassie Stain were from Bio-Rad (Hercules, CA). Dithionite, dithiothreitol (DTT), Invitrogen Novex NativeMARK ${ }^{\mathrm{mm}}$ Protein Standards, and all other chemicals were purchased from Fisher Scientific, unless otherwise specified.

\subsection{Production and Purification of $\mathrm{His}_{6}-\mathrm{DmrB}$}

Burkholderia xenovorans $\mathrm{DmrB}$ with an $\mathrm{N}$-terminal histidine tag $\left(\mathrm{His}_{6}\right.$-DmrB) was produced in Escherichia coli BL21 (DE3) RIL cells (Stratagene, La Jolla, CA) containing pET41a:his 6 -DmrB, and cells were harvested by centrifugation, as described previously by McNamara et al. [12]. The cell pellet (about $3 \mathrm{~g}$ ) was thawed from $-20^{\circ} \mathrm{C}$ and suspended in lysis buffer $(50 \mathrm{mM}$ tris(hydroxymethyl)aminomethane (Tris), $\mathrm{pH} 8.0,200 \mathrm{mM} \mathrm{NaCl}, 20 \mathrm{mM}$ imidazole) at a ratio of $2 \mathrm{ml}$ of buffer per $\mathrm{g}$ of cell pellet. Cells were lysed using a 
French Press (Thermo-Fisher Scientific) at 20,000 psi and centrifuged at 32,000 $\times \mathrm{g}$ for $30 \mathrm{~min}$. The supernatant (cell-free extract, CFE) was mixed with nickel nitrilotriacetic acid (Ni-NTA) agarose beads (Qiagen, Chatsworth, CA) $(0.25 \mathrm{ml}$ of beads per $\mathrm{ml}$ of $\mathrm{CFE}$ ) and incubated on ice with gentle rocking for $2 \mathrm{~h}$. The beads were then poured in a plastic $10-\mathrm{ml}$ column (Bio-Rad, Hercules, CA), and the flow-through fraction was collected. The beads were washed three times with $5 \mathrm{ml}$ of wash buffer (50 mM Tris, $\mathrm{pH} 8.0,200 \mathrm{mM} \mathrm{NaCl}, 30 \mathrm{mM}$ imidazole).

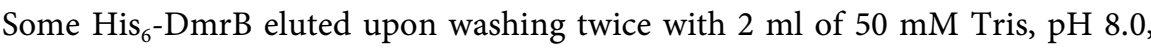
$200 \mathrm{mM} \mathrm{NaCl}, 100 \mathrm{mM}$ imidazole, but more highly purified protein ( 95\% pure) eluted with two additions of elution buffer $(2 \mathrm{ml})$ containing $250 \mathrm{mM}$ imidazole. The protein was stored at $4^{\circ} \mathrm{C}$ until use.

\subsection{Production and Purification of $\mathrm{His}_{6}$-Fre from Salmonella enterica}

A codon-optimized gene encoding an $\mathrm{NAD}(\mathrm{P}) \mathrm{H}$-flavin reductase (Fre) from $S$. enterica (NP_462864.1) [14] with an N-terminal six-histidine tag ( $\mathrm{His}_{6}$-Fre) was synthesized by GenScript (Piscataway, NJ), subcloned into the NdeI-HinDIII sites of pET41a, and transformed into E. coli BL21(DE3)-RIL cells. Cells were grown and harvested in the same manner as for $\mathrm{DmrB}$, and protein was purified aerobically using the same protocol as $\mathrm{DmrB}$, except that $\mathrm{His}_{6}$-Fre tended to elute in $100 \mathrm{mM}$ imidazole. All centrifugation and incubation steps were carried out at $4^{\circ} \mathrm{C}$.

$\mathrm{His}_{6}$-Fre could be stored in its elution buffer and could remain stable for at least one month at $4^{\circ} \mathrm{C}$ in that buffer. However, $\mathrm{His}_{6}$-Fre was found to be sensitive to temperature fluctuations when stored in a refrigerator that was opened and closed frequently. Therefore, the active fraction (Elution 1, $100 \mathrm{mM}$ imidazole) was separated into $200-\mu \mathrm{l}$ aliquots, sealed in $2-\mathrm{ml}$ vials, and kept in a $4^{\circ} \mathrm{C}$ cold room to minimize temperature fluctuations. For enzymatic studies, $\mathrm{His}_{6}$-Fre was maintained at $4^{\circ} \mathrm{C}$, either on ice or on Lab Armor cold beads (Fisher Scientific).

\subsection{Dithionite and Dithiothreitol (DTT) Electron Transfer Assay}

Electron transfer assays were conducted anaerobically in a chamber containing $98 \% \mathrm{~N}_{2}$ and $2 \% \mathrm{H}_{2}$ (Coy Laboratories, Grass Lake, MI) or in anaerobic cuvettes sealed with Teflon-lined silicon septa. Solutions were purged with a flow of $\mathrm{N}_{2}$ gas and then brought into the anaerobic chamber. If proteins were to be stored in the absence of $\mathrm{O}_{2}$ after purification, samples were placed inside an anaerobic chamber and 2-mercaptoethanol was added to a final concentration of $15 \mathrm{mM}$.

Dithionite (10 $\mathrm{mM}$ ) and DTT (up to $50 \mathrm{mM}$ ) were tested as artificial electron donors for $\mathrm{His}_{6}$-DmrB by monitoring a decrease in the flavin absorbance peaks at 380 and $460 \mathrm{~nm}$ with either a Beckman model DU-800 spectrophotometer (Beckman Coulter, Inc., Brea, CA) using sealed anaerobic quartz cuvettes or a Bio-Rad SmartSpec Plus inside an anaerobic chamber. For dithionite reduction, 
purified protein $\left(\sim 1.25 \mathrm{mg}\right.$ of $\left.\mathrm{His}_{6}-\mathrm{DmrB}\right)$ was diluted to $990 \mu \mathrm{l}$ with $20 \mathrm{mM}$ Tris, $\mathrm{pH}$ 8.0, $100 \mathrm{mM}$ sodium chloride, $5 \%$ glycerol and then mixed with $10 \mu \mathrm{l}$ of $1 \mathrm{M}$ dithionite. For DTT reduction tests, $50 \mu \mathrm{l}$ of $1 \mathrm{M}$ DTT and $1.25 \mathrm{mg}$ of protein in $950 \mu \mathrm{l}$ of $20 \mathrm{mM}$ Tris, $\mathrm{pH} 8.0,100 \mathrm{mM}$ sodium chloride, $5 \%$ glycerol were mixed.

\subsection{Development of Small-Scale Flavin Reductase (Fre) Assay}

A ping-pong mechanism for DmrB has been proposed in which an enzyme (Fre) reduces a loosely bound FMN cofactor (FMN-2) of DmrB [12]. To begin to test this hypothesis, an assay using Fre from $S$. enterica [14] was developed by monitoring a decrease in the flavin absorbance peaks at 380 and $460 \mathrm{~nm}$ in the presence of NADH and Fre with a six-histidine tag ( $\mathrm{His}_{6}$-Fre). To conserve protein resources, a small-scale $(200 \mu \mathrm{l})$ assay was also developed using a Bio-Rad SmartSpec Plus and plastic trUView cuvettes (Bio-Rad) inside the anaerobic chamber. Stock solutions of [ $5 \mathrm{mM} F M N$ in $20 \mathrm{mM}$ Tris $\mathrm{pH}$ 8.0] and [10 $\mathrm{mM}$ $\mathrm{NADH}$ in $50 \mathrm{mM}$ 3-(N-morpholino)propanesulfonic acid (MOPS), $\mathrm{pH} 6.8$ ] were used. The standard assay $(200 \mu \mathrm{l})$ consisted of $194 \mu \mathrm{l}$ of $50 \mathrm{mM}$ MOPS, pH 7.0, 2 $\mu \mathrm{l}$ of $5 \mathrm{mM}$ FMN (50 $\mu \mathrm{M}$ final concentration) and $2 \mu \mathrm{l}$ of $10 \mathrm{mM}$ NADH (100 $\mu \mathrm{M}$ final concentration). Although an E. coli version of Fre is reported to use both NADH and NADPH as co-substrates [15] [16], under the conditions studied in the current work, the $S$. enterica His $_{6}$-Fre could use only NADH efficiently. The reaction was initiated by addition of $2 \mu \mathrm{l}$ of $\mathrm{His}_{6}$-Fre enzyme (stock enzyme concentration was 2 to $2.5 \mathrm{mg}$ protein $/ \mathrm{ml}$ ).

For experiments to estimate the reaction rate, the protein amounts used above were too high, and thus the enzyme solution was diluted 50 -fold with assay buffer. His $_{6}$-Fre was kept on $4^{\circ} \mathrm{C}$ beads during these assays since it would lose activity at higher temperatures throughout the day, as described above. For studies in the absence of exogenous FMN, the standard assay $(200 \mu \mathrm{l})$ included $196 \mu \mathrm{l}$ of enzyme and $2 \mu \mathrm{l}$ of $10 \mathrm{mM}$ NADH (100 $\mu \mathrm{M}$ final). The reaction was initiated by the addition of $\mathrm{His}_{6}$-Fre. The solution buffering the enzyme was used as assay buffer.

\subsection{NADH/Fre Electron Transfer Assay (1-ml)}

All assays were conducted anaerobically. $\mathrm{His}_{6}-\mathrm{DmrB}(2.5 \mathrm{mg})$ was diluted with $983 \mu \mathrm{l}$ of assay buffer (20 mM Tris, $\mathrm{pH} 8.0,100 \mathrm{mM}$ sodium chloride, $5 \%$ glycerol), and then $10 \mu \mathrm{l}$ of $10 \mathrm{mM} \mathrm{NADH}(100 \mu \mathrm{M}$ final concentration) and $7 \mu \mathrm{l}$ of $3.33 \mu \mathrm{g} / \mu \mathrm{l} \mathrm{His}{ }_{6}$-Fre $(20 \mu \mathrm{g})$ were added $(1 \mathrm{ml}$ final volume). No exogenous FMN was added. NADPH (100 $\mu \mathrm{M}$ final concentration) was also tested as an artificial electron donor in the presence of $\mathrm{His}_{6}$-Fre.

\subsection{Breakage of M. thermophila Cells and Storage of Cell-Free Extracts for Carbon Monoxide Dehydrogenase (CODH)/Ferredoxin Studies}

Methanogen Methanosarcina thermophila cells were previously grown on ace- 
tate by Joseph Scott (University of Florida, Gainesville), stored in liquid $\mathrm{N}_{2}$, and lysed as described previously [17]. Cells (2.5 g) were mixed with breakage buffer (5 $\mathrm{ml}$ of $50 \mathrm{mM}$ TES, $\mathrm{pH} 7.0,10 \mathrm{mM} \mathrm{MgCl}, 5 \%$ glycerol, and $10 \mathrm{mM}$ 2-mercaptoethanol) and $2 \mu \mathrm{l}$ DNase and broken anaerobically with one passage using a cold $\left(4^{\circ} \mathrm{C}\right)$ French Press (ThermoScientific). After anaerobic centrifugation at $32,000 \times \mathrm{g}\left(4^{\circ} \mathrm{C}\right)$ for $45 \mathrm{~min}$, the supernatant (cell-free extract) was flash-frozen and stored as pellets in liquid $\mathrm{N}_{2}$ until use.

\subsection{Electron Transfer to DmrB via CO and M. thermophila Extracts}

It has previously been shown that $\mathrm{CO}$ and extracts of the sulfate-reducing archaeon Archaeoglobus fulgidus could be used to reduce archaeal flavoprotein A (AfpA), a DmrB homolog from A. fulgidus [11]. Electrons from CO presumably flow to a large carbon monoxide dehydrogenase (CODH) complex in the extracts, where they are transferred to a ferredoxin or a ferredoxin-like protein, and then to an archaeal flavoprotein AfpA [11] that is a homolog of DmrB. Using similar reasoning, we tested the ability of $\mathrm{CO}$ and extracts from the methanogen $M$. thermophila to reduce purified $\mathrm{His}_{6}$-DmrB.

$\mathrm{His}_{6}-\mathrm{DmrB}$ was purified as described above and stored at $4^{\circ} \mathrm{C}$ until use. Enzyme solutions were centrifuged before use and then desalted using prepacked 8.3-ml columns of Sephadex G-25 (GE Healthcare, Marlborough, MA, purchased from Fisher Scientific) to separate any FMN that might have become unbound during storage.

Initial absorbance values at $340 \mathrm{~nm}$ and $460 \mathrm{~nm}$ of a small sample $(100 \mu \mathrm{l})$ of as-purified $\mathrm{His}_{6}$-DmrB were determined using plastic trUView cuvettes (Bio-Rad) and a Bio-Rad Smart-Spec Plus spectrophotometer to establish an amount within the detection limit of the instrument [1.5 absorbance units (AU) or less]. If on-scale, then a quartz cuvette was sealed anaerobically and flushed with $\mathrm{CO}$ (or $\mathrm{N}_{2}$ for controls) for 3 min to clear away any $\mathrm{O}_{2}$ that would interfere with reduction studies. Using anaerobic technique, $1 \mathrm{ml}$ of $\mathrm{His}_{6}$-DmrB protein sample was injected into the CO-flushed quartz cuvette and an initial reading at $460 \mathrm{~nm}$ was taken. A Beckman model DU-640 spectrophotometer (Beckman Coulter) was used for this and continuing steps. Using an anaerobic syringe, $5 \mu \mathrm{l}$ of $M$. thermophila cell extract containing $\mathrm{CODH}$ was injected into the cuvette containing CO and $\mathrm{His}_{6}-\mathrm{DmrB}$. FMN reduction was followed at $460 \mathrm{~nm}\left(\varepsilon_{460 \mathrm{~nm}}\right.$ $\left.=12,500 \mathrm{M}^{-1} \cdot \mathrm{cm}^{-1}\right)[18]$.

\subsection{Production and Purification of $\mathrm{His}_{6}$-MM1853}

To produce an expression plasmid for heterologous protein production, a DNA sequence encoding MM1853 (accession number AAM31549.1) with an $\mathrm{N}$-terminal histidine tag ( $\left.h i s_{6}-M M 1853\right)$ was synthesized by GenScript with codon optimization for E. coli. The modified gene was cloned first into pUC57 and then subcloned into the NdeI and BamHI sites of the pET41a expression vector 
(Novagen). Chemically competent BL21(DE3)-RIL cells were transformed and selected on plates containing $50 \mu \mathrm{g}$ kanamycin/ml, creating the cell line MP01.

For $\mathrm{His}_{6}-\mathrm{MM} 1853$ production, $1 \mathrm{~L}$ of LB broth with kanamycin $(50 \mu \mathrm{g} / \mathrm{ml})$ was inoculated with $25 \mathrm{ml}$ of an overnight culture of MP01 cells and incubated with shaking $(180 \mathrm{rpm})$ at $37^{\circ} \mathrm{C}$ until an $\mathrm{OD}_{600}$ of 0.6 was reached. Gene expression was induced with IPTG to $1 \mathrm{mM}$. After $6 \mathrm{~h}$ of incubation at $30^{\circ} \mathrm{C}$, the cells were harvested using a Sorvall RC-5C Plus centrifuge (Fisher Scientific) with an F9 rotor at $5000 \mathrm{rpm}(4700 \times \mathrm{g})$ at $4^{\circ} \mathrm{C}$ for $15 \mathrm{~min}$. The cell pellet was washed with $30 \mathrm{ml}$ of $50 \mathrm{mM}$ Tris, $\mathrm{pH} 8.0$, and the cells were centrifuged in an F13 rotor at $5000 \mathrm{rpm}(4300 \times \mathrm{g})$. The pellet was stored at $-80^{\circ} \mathrm{C}$ until use.

During the aerobic purification of $\mathrm{His}_{6}-\mathrm{MM} 1853$, all manipulations were carried out on ice. Frozen E. coli (MP01) cells ( $3 \mathrm{~g}$ wet weight from $1 \mathrm{~L}$ of medium) were suspended in $6 \mathrm{ml}$ of lysis buffer (50 mM Tris, pH 8.0, $200 \mathrm{mM}$ sodium chloride, $20 \mathrm{mM}$ imidazole). The cells were broken using a French press and centrifuged as described for DmrB. The supernatant (cell-free extract, CFE) was mixed with $1.5 \mathrm{ml}$ of Ni-NTA agarose and incubated with shaking on ice for $2 \mathrm{~h}$. The column was developed as described above for the purification of $\mathrm{His}_{6}$-DmrB.

Protein concentrations were measured using the Bradford assay [19] with bovine serum albumin (Bio-Rad) as the standard. SDS-PAGE [20] with Bio-Safe ${ }^{\mathrm{TM}}$ Coomassie Stain (Bio-Rad) was used to analyze protein solubility and purity.

\subsection{Electron Transfer Assays Using Dithiothreitol (DTT), NADH/Fre, or NADPH/Fre}

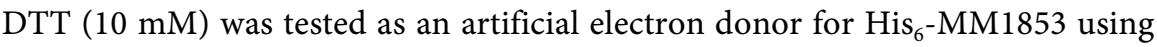
$\sim 1.25 \mathrm{mg}$ of purified protein in a final volume of $1 \mathrm{ml}$ with the same protocol described for $\mathrm{His}_{6}$-DmrB. In addition, the NADH/Fre system was tested for the ability to reduce $\mathrm{His}_{6}-\mathrm{MM} 1853(0.5 \mathrm{mg}$ of protein in a final volume of $1 \mathrm{ml})$ as described for $\mathrm{His}_{6}-\mathrm{DmrB}$. The ability of NADPH to serve as an electron donor in the presence of $\mathrm{His}_{6}$-Fre was also examined using an NADPH concentration of $100 \mu \mathrm{M}$.

\section{Results}

\subsection{Effect of Chemical Reductants on the FMN Prosthetic Group of His $_{6}$-DmrB}

The first step in developing an activity assay for DmrB is to identify an electron donor that reduces the FMN prosthetic group of the enzyme without directly reducing the substrate (dihydromethanopterin) through a nonenzymatic process. The UV-visible absorbance spectrum of oxidized FMN has peaks near 278,380 , and $460 \mathrm{~nm}$; therefore, the ability of different chemical compounds to reduce the tightly bound FMN of $\mathrm{His}_{6}-\mathrm{DmrB}$ can be conveniently measured as a decrease in the absorbance at these wavelengths. Initially, several common chemical electron donors were selected for analysis. These included dithionite, 
with a standard redox potential at $\mathrm{pH} 7$ of $-0.66 \mathrm{~V}$, compared to FMN $(-0.207$ V) (21), dithiothreitol (DTT, $-0.33 \mathrm{~V})$ [21], $\beta$-mercaptoethanol (-0.26 V) [22], and NADH $(-0.32 \mathrm{~V})$.

Treatment with the powerful reductant dithionite rapidly reduced the tightly bound FMN of $\mathrm{His}_{6}$-DmrB (data not shown), as observed previously for the archaeal flavoprotein homologs AfpA and DmrX [10] [11]. Unfortunately, dithionite is too strong for use in a DmrB assay because it can also nonenzymatically reduce the substrate dihydromethanopterin. We then tested DTT at concentrations from 30 to $100 \mathrm{mM}$, but DTT was unable to reduce the FMN prosthetic group of $\mathrm{His}_{6}$-DmrB over the period of one hour (Figure 2). This result was unexpected since DTT effectively reduces the archaeal homolog DmrX and has been used to develop a successful activity assay for that enzyme [10]. We hypothesize that the $4 \mathrm{Fe}-4 \mathrm{~S}$ clusters of DmrX may facilitate electron transfer to FMN in the archaeal dihydromethanopterin reductases, while the lack of iron-sulfur clusters in $\mathrm{His}_{6}$-DmrB may prevent the use of DTT as an electron donor. Neither $\mathrm{NAD}(\mathrm{P}) \mathrm{H}$ nor $\beta$-mercaptoethanol could influence the absorbance peaks of DmrB (data not shown), which is consistent with the published results for DmrX and AfpA [10] [11].

\subsection{DmrB Reduction Using an NADH/Fre Electron Transfer System}

Having failed to identify a chemical reductant suitable for a DmrB assay among our selected chemical candidates, we next examined the hypothesis of $\mathrm{McNa}$ mara et al. (12) that an electron transport system consisting of exogenous FMN, $\mathrm{NADH}$, and $\mathrm{NAD}(\mathrm{P}) \mathrm{H}$-dependent flavin reductase (Fre) may provide electrons to DmrB. Preliminary experiments in the laboratory provided ambiguous yet promising preliminary results that $\mathrm{NADH}$ combined with exogenous FMN and

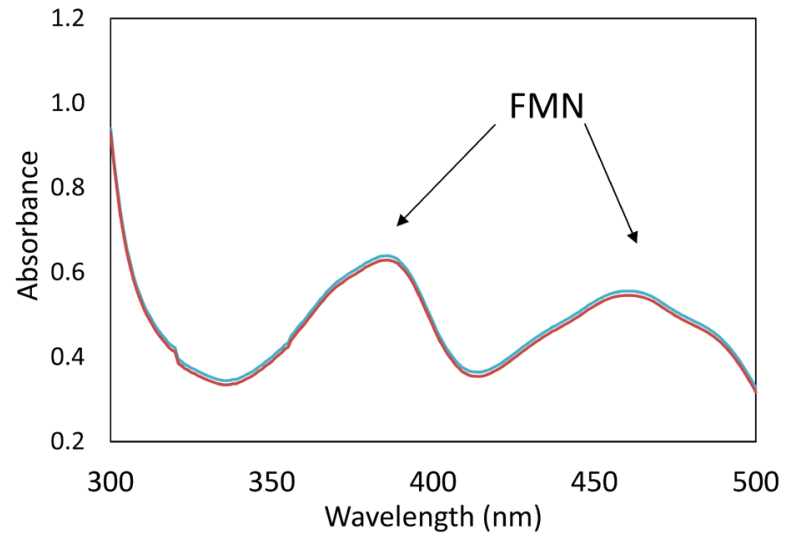

Figure 2. Effect of DTT on the FMN prosthetic group of His $_{6}$-DmrB. DTT (100 mM) was added to desalted His $_{6}-$ DmrB $(10 \mu \mathrm{M})$ as described in Materials and Methods, and a spectrum was taken at 5 min intervals for 60 min. For clarity, only the spectra at $0 \mathrm{~min}$ (red line) and 60 min (blue line) are shown. 
recombinant $S$. enterica Fre could partially reduce the flavin peaks of $\mathrm{His}_{6}-\mathrm{DmrB}$ (unpublished data). Moreover, in a control experiment omitting exogenous FMN, the remaining components (NADH and Fre) unexpectedly appeared sufficient to partially reduce the FMN prosthetic group of $\mathrm{His}_{6}$-DmrB.

To investigate these results in a more systematic way, we first purified $\mathrm{His}_{6}$-DmrB using meticulous anaerobic technique and recorded the UV-visible spectrum from 300 to $550 \mathrm{~nm}$ (Figure 3(a), line 1). Upon addition of NADH, the NADH peak at $340 \mathrm{~nm}$ interfered with the flavin peak of DmrB at $380 \mathrm{~nm}$ (Figure 3(a), line 2), and thus only the second flavin peak near $460 \mathrm{~nm}$ was used monitor electron flow between the electron donor system and $\mathrm{His}_{6}-\mathrm{DmrB}$. When the reduction assay was initiated by adding $20 \mu \mathrm{g}$ of $\mathrm{His}_{6}$-Fre, a slight increase (0.050 absorbance unit at $460 \mathrm{~nm}$ ) was initially observed (data not shown), indicating that the injected solution might not have been fully anaerobic. However, after $10 \mathrm{~min}$, a decrease of 0.163 absorbance unit was observed (Figure 3(a), line 2 ), and the absorbance continued to decrease in subsequent time points. In a

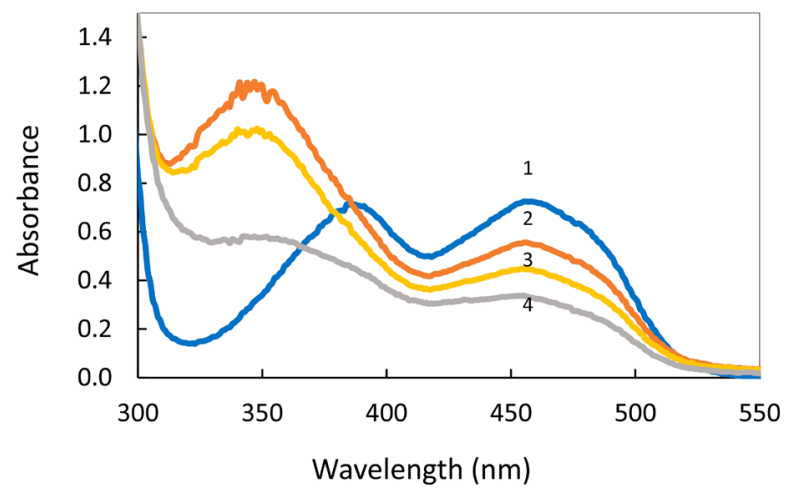

(a)

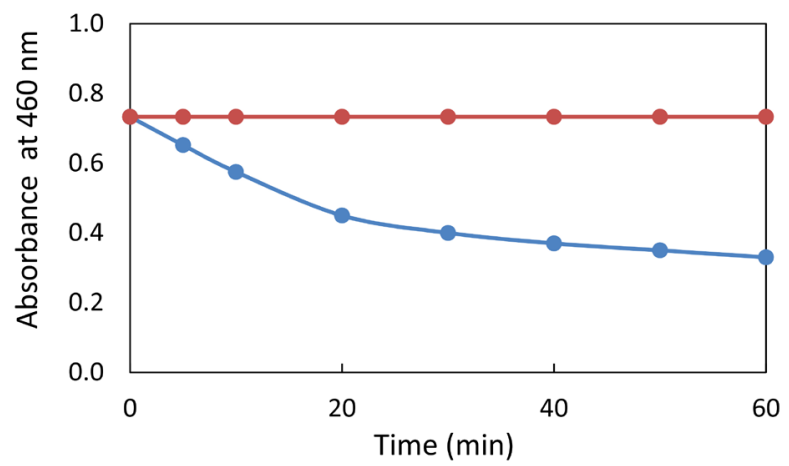

(b)

Figure 3. Fre-mediated reduction of $\mathrm{His}_{6}-\mathrm{DmrB}$ with $\mathrm{NADH}$ and $\mathrm{His}_{6}$-Fre. (a) In the presence of 20 ug of $\mathrm{His}_{6}$-Fre, NADH $(100 \mu \mathrm{M})$ could reduce His ${ }_{6}$-DmrB $(2.5 \mathrm{mg})$ in a final volume of $1 \mathrm{ml}$. The FMN spectrum was examined at $5 \mathrm{~min}$ intervals, and data the selected time points are shown: $0 \mathrm{~min}$ (line 1), $15 \mathrm{~min}$ (line 2), $30 \mathrm{~min}$ (line 3), and 65 min (line 4); (b) Time course for the reduction of $\mathrm{His}_{6}-\mathrm{DmrB}$ by NADH/Fre. Each 100 -ul assay contained $\mathrm{His}_{6}-\mathrm{DmrB}(50 \mathrm{ug})$ and $100 \mu \mathrm{M}$ NADH. The absorbance at $460 \mathrm{~nm}$ was monitored at 10 -min intervals after adding $20 \mu \mathrm{g}$ of $\mathrm{His}_{6}$-Fre to heated-inactivated $\mathrm{His}_{6}$-DmrB as a control (red line) or native $\mathrm{His}_{6}-\mathrm{DmrB}$ (blue line). 
typical experiment, the reaction appeared to be complete within about $65 \mathrm{~min}$ (Figure 3(a), line 4), since the 460-nm peak did not decrease substantially at later time points. The decrease in absorbance at $460 \mathrm{~nm}$ is consistent with electron transfer from NADH to Fre to DmrB; however, contrary to the prediction of the ping-pong mechanism [12], exogenous FMN did not appear to be a requirement for Fre-mediated electron transfer to DmrB.

To quantify the rate of $\mathrm{His}_{6}-\mathrm{DmrB}$ reduction in each time interval by the $\mathrm{NADH} /$ Fre system using the molar extinction coefficient for FMN at $460 \mathrm{~nm}$ $\left(12,500 \mathrm{M}^{-1} \cdot \mathrm{cm}^{-1}\right)[18]$, the following equation was used:

$$
\begin{aligned}
& {\left[\mathrm{His}_{6}-\mathrm{DmrB} \mathrm{FMN}_{\text {reduced }}\right] / \mathrm{min}} \\
& =\Delta \mathrm{Abs}_{460 \mathrm{~nm}} / 12,500 \mathrm{M}^{-1} \cdot \mathrm{cm}^{-1} / \text { assay interval }(\mathrm{min})
\end{aligned}
$$

To estimate an initial rate of $\mathrm{His}_{6}-\mathrm{DmrB}$ reduction, the absorbance at $460 \mathrm{~nm}$ was monitored at $5 \mathrm{~min}$ intervals, and the data points at $0 \mathrm{~min}, 5 \mathrm{~min}$, and 10 min were used for calculating the velocity. In this experiment, the initial absorbance of $\mathrm{His}_{6}$-DmrB at $460 \mathrm{~nm}$ was 0.733 (Figure 3(b), blue line). After $5 \mathrm{~min}$, a decrease of 0.081 absorbance unit was observed, corresponding to a reduction rate of $1.3 \mu \mathrm{M} / \mathrm{min}$. In the interval from $5 \mathrm{~min}$ to $10 \mathrm{~min}$, the absorbance decreased by $0.077(1.2 \mu \mathrm{M} / \mathrm{min}$ ). Over the next 10-min interval (from 10 to 20 $\mathrm{min}$ ), the rate dropped to $0.522 \mu \mathrm{M} / \mathrm{min}$. As a control, when was $\mathrm{His}_{6}$-Fre inactivated by heat, no loss of absorbance at $460 \mathrm{~nm}$ was observed (Figure 4(b), red line).

\subsection{DmrB Reduction Using CO, CO Dehydrogenase (CODH), and Ferredoxin}

Ding and Ferry [11] showed previously that archaeal flavoprotein (AfpA, an archaeal homolog of $\mathrm{DmrB}$ ) could be reduced by $\mathrm{CO}$ in the presence of $\mathrm{CODH}$ and ferredoxin. Both AfpA and DmrB lack iron-sulfur clusters, raising the possibility that the archaeal $\mathrm{CO} / \mathrm{CODH} /$ ferredoxin system may act as an artificial electron donor system for $\mathrm{His}_{6}$-DmrB in vitro. When $2 \mu \mathrm{M} \mathrm{His}_{6}$-DmrB in $1 \mathrm{ml}$ of anaerobic buffer was incubated with an atmosphere of $\mathrm{CO}$, the FMN cofactor remained oxidized (Figure 4, line 1). However, when the reduction assay was initiated by adding $10 \mu \mathrm{l}$ of partially purified CODH-ferredoxin, a sudden decrease of 0.105 absorbance unit was immediately observed (Figure 4, line 2). After $3 \mathrm{~min}$, a further decrease of 0.05 absorbance unit occurred (Figure 4, line 3). The reaction appeared to be complete within 6 min since the $460-\mathrm{nm}$ peak did not decrease substantially at later time points. $\mathrm{His}_{6}$ - $\mathrm{DmrB}$ remained reduced, and re-oxidation of the flavin was not observed within two hours of adding $\mathrm{CODH} /$ ferredoxin (data not shown). The decrease in absorbance at $460 \mathrm{~nm}$ is consistent with rapid electron transfer from $\mathrm{CODH}$ through ferredoxin to $\mathrm{His}_{6}$-DmrB. Thus, the archaeal CODH-ferredoxin system from M. thermophila can be used successfully as an artificial electron donor for $\mathrm{His}_{6}$-DmrB from the bacterium B. xenovorans. 


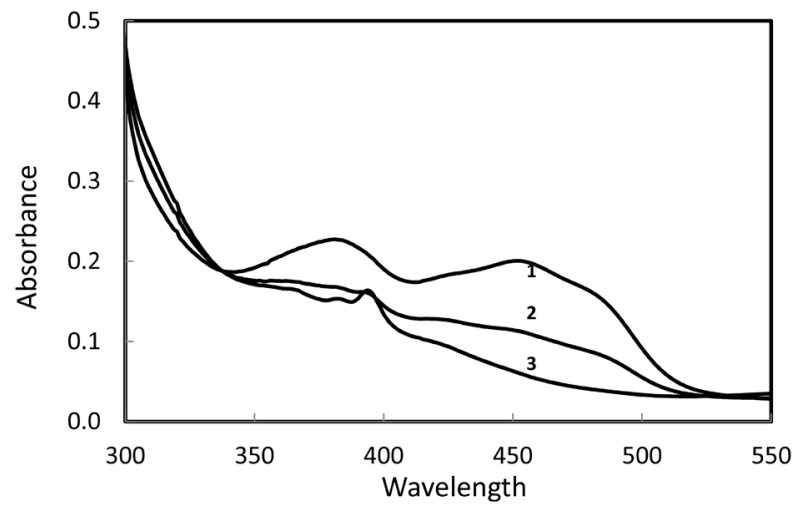

(a)

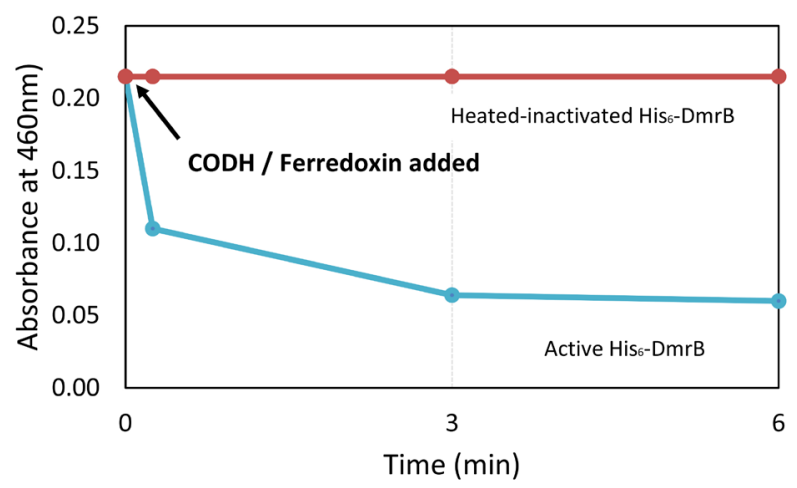

(b)

Figure 4. Reduction of $\mathrm{His}_{6}$-DmrB by CODH/ferredoxin. (a) The absorbance spectrum was examined at 3-min intervals. Data from following time points are shown: 0 min (line 1), 0 min immediately after adding CODH-ferredoxin (line 2), and after 3 min (line 3); (b) Absorbance at $460 \mathrm{~nm}$ at $0 \mathrm{~min}$ (initial), immediately after adding extract with $\mathrm{CODH} /$ ferredoxin, and $3 \mathrm{~min}$ later in the presence of heat-inactivated $\mathrm{His}_{6}$-DmrB (control, line 1) and active $\mathrm{His}_{6}$-DmrB (line 2).

When the assay was initiated by adding $\mathrm{CODH}$ and ferredoxin, the rate could not be measured accurately because the first decrease to 0.105 absorbance units occurred within 15 seconds of adding the catalyst. In the time it took to mix and record the first absorbance reading, the reduction was nearly two-thirds complete. A general approximation of a rate might be made by dividing the change in absorbance by the extinction coefficient and $0.25 \mathrm{~min}$, which gives an estimate of about $34 \mu \mathrm{M}$ FMN reduced/min. After $3 \mathrm{~min}$, an additional decrease of 0.046 absorbance unit was observed with a corresponding rate of $1.22 \mu \mathrm{M} / \mathrm{min}$.

\subsection{Reduction of $\mathrm{His}_{6}$-MM1853}

A second flavoprotein, MM1853 from the methanogen Methanosarcina mazei, has homology to the Orf19 protein of $M$. extorquens. These proteins have been hypothesized to play a role in $\mathrm{H}_{4} \mathrm{MPT}$ biosynthesis based on mutagenesis studies in $M$. extorquens showing that deletion of the orf 19 gene abolishes the ability to synthesize $\mathrm{H}_{4} \mathrm{MPT}$ [13]. Because the crystal structure of MM1853 (pdb 2NR4) contains one FMN per subunit, we predict that the enzyme functions as an oxi- 
doreductase required for $\mathrm{H}_{4} \mathrm{MPT}$ biosynthesis. However, this protein has not yet been characterized biochemically. In this work, we tested the ability of MM1853 to be reduced by the same electron donor candidates as for $\mathrm{His}_{6}$-DmrB. The gene for MM1853 was overexpressed in E. coli cells, and after cell lysis and centrifugation, about $90 \%$ of the $\mathrm{His}_{6}$-MM1853 appeared to be soluble, as shown by the distribution of the $23-\mathrm{kDa}$ protein between the cell-free extract and insoluble pellet in SDS-PAGE (Figure 5, lanes 3 and 4). The molecular mass of the overproduced protein is similar to the predicted molecular mass of $\mathrm{His}_{6}-\mathrm{MM} 1853$ based on the amino acid sequence (approximately $21.6 \mathrm{kDa}$ ) plus the mass of the six-histidine tag. The target protein $\mathrm{His}_{6}$-MM1853 was purified by Ni-NTA chromatography. Although $\mathrm{His}_{6}-\mathrm{MM} 1853$ was abundant in the fractions eluted with $100 \mathrm{mM}$ imidazole, this fraction was contaminated with three additional proteins (Figure 5, lane 7). When $\mathrm{His}_{6}$-MM1853 was eluted with $250 \mathrm{mM}$ imidazole, a single $23-\mathrm{kDa}$ band was observed on the SDS-PAGE gel (Figure 5, lane 8). The purified protein had a yellow color, consistent with the presence of FMN.

\subsection{Test of DTT and NAD(P)H as Reductants for MM1853}

DTT $(10 \mathrm{mM})$ reduced the FMN of $\mathrm{His}_{6}$-MM1853 by about $20 \%$ within the first 5 min of adding reductant, indicated by a decrease in the absorbance peaks at $380 \mathrm{~nm}$ and $460 \mathrm{~nm}$ (Figure 6, trace 2). By $30 \mathrm{~min}$, the FMN appeared completely reduced (Figure 6 , trace 3 ). Therefore, in contrast to the result with $\mathrm{His}_{6}$-DmrB (Figure 3), $\mathrm{His}_{6}-\mathrm{MM} 1853$ was able to receive electrons from DTT. $\mathrm{NADH}$ and NADPH were also examined for the ability to donate electrons directly to the cofactor of $\mathrm{His}_{6}-\mathrm{MM} 1853$. However, neither NADH nor NADPH

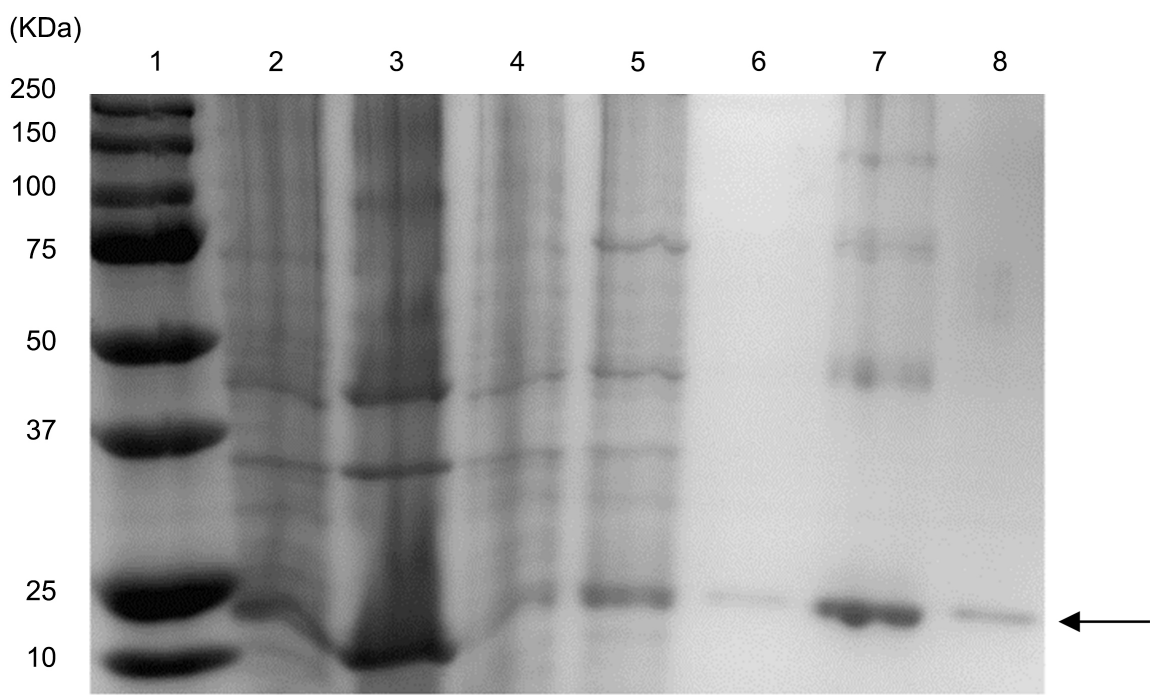

Figure 5. SDS-PAGE of $\mathrm{His}_{6}$-MM1853 purification. Purification of $\mathrm{His}_{6}$-MM1853. Lanes: (1) Precision Plus Protein ${ }^{\mathrm{TM}}$ Dual Color Standards (Bio-Rad, Hercules, CA, USA); (2) induced cells; (3) cell-free extract; (4) insoluble pellet; (5) $30 \mathrm{mM}$ imidazole, Wash 1; (6) $100 \mathrm{mM}$ imidazole, Elution 1; (7) $100 \mathrm{mM}$ imidazole, Elution 2; (8) $250 \mathrm{mM}$ imidazole, Elution 3. The arrow indicates the position of $\mathrm{His}_{6}-\mathrm{MM} 1853$. 
could directly transfer electrons to $\mathrm{His}_{6}-\mathrm{MM} 1853$ without $\mathrm{His}_{6}$-Fre added (Figure 7, line 1).

\subsection{NADH/Fre Enzyme Reduction of MM1853}

Because NADH alone was unable to reduce the FMN of $\mathrm{His}_{6}-\mathrm{MM} 1853$, we tested whether $\mathrm{His}_{6}$-Fre could facilitate electron transfer from NADH to $\mathrm{His}_{6}-\mathrm{MM} 1853$. When the assay was initiated by adding $\mathrm{His}_{6}$-Fre, a decrease of 0.135 absorbance unit was observed compared to the original absorbance at $380 \mathrm{~nm}$, while the 460-nm peak was decreased completely to baseline level (Figure 7, line 2). For the 460-nm peak, the reaction appeared to be complete within 5 min since the absorbance at this wavelength did not decrease substantially at later time points (Figure 7, lines 3 and line 4). After $15 \mathrm{~min}$, a further slight decrease of $0.007 \mathrm{ab}$ sorbance unit was observed only at $380 \mathrm{~nm}$ (Figure 7, line 3), which might

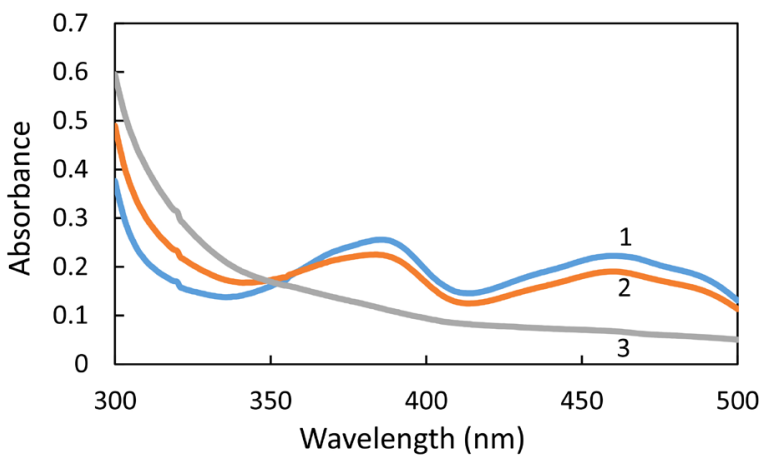

Figure 6. Reduction of $\mathrm{His}_{6}$-MM1853 using DTT. Purified His $_{6}$-MM1853 (10 $\mu \mathrm{M}$, line 1) was treated with $10 \mathrm{mM}$ DTT, which began to reduce the peaks at $380 \mathrm{~nm}$ and 460 $\mathrm{nm}$ within $5 \mathrm{~min}$ (line 2) and resulted in complete reduction by $30 \mathrm{~min}$ (line 3 ).

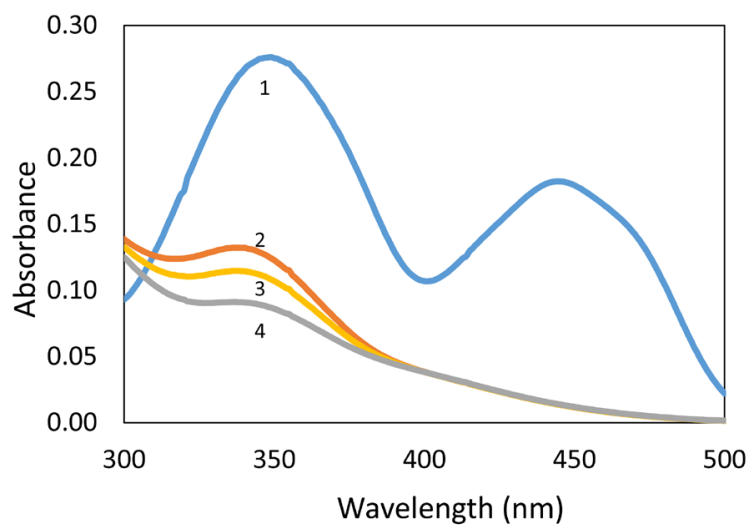

Figure 7. Effect of $\mathrm{His}_{6}$-Fre on reduction of $\mathrm{His}_{6}$-MM1853 by $\mathrm{NADH}$. NADH alone could not reduce $10 \mu \mathrm{M}$ His $_{6}$-MM1853 in the absence of $\mathrm{His}_{6}$-Fre (line 1). However, the characteristic FMN peaks at 380 and $460 \mathrm{~nm}$ decreased after adding $20 \mu \mathrm{g}$ of $\mathrm{His}_{6}$-Fre: $5 \mathrm{~min}$ (line 2), $15 \mathrm{~min}$ (line 3) and $30 \mathrm{~min}$ (line 4). 
correspond to $\mathrm{NADH}$ oxidation. The decrease in peaks corresponding to oxidized FMN is consistent with electron transfer from NADH through Fre to MM1853. Thus, the NADH/Fre system can be used as a convenient and effective electron donor system for MM1853.

\section{Discussion}

This research has characterized electron transfer reactions for two flavoprotein oxidoreductases associated with $\mathrm{H}_{4} \mathrm{MPT}$ biosynthesis: $\mathrm{DmrB}$ from a beta-proteobacterium and MM1853 from an archaeal methanogen. The main goal was to find an electron donor that efficiently reduces the FMN prosthetic group as the first critical step towards creating new activity assays to test hypotheses about the enzyme function and mechanism. In the case of DmrB, an air-stable homolog of the $\mathrm{O}_{2}$-sensitive methanogen enzyme DmrX, a facile enzyme assay may have broad application as a model enzyme for high-throughput screening of potential methanogenesis inhibitors that function by blocking $\mathrm{H}_{4} \mathrm{MPT}$ biosynthesis. For MM1853, the assay would play a critical role in discovering the function of this as yet uncharacterized catalyst in the pathway of $\mathrm{H}_{4} \mathrm{MPT}$ biosynthesis.

The bacterial protein DmrB has been proposed to originate from the horizontal transfer of a gene coding for methanogen DmrX/AfpA [9]. This example of gene transfer from the Archaea domain to the Bacteria domain would require evolutionary changes to adapt the enzyme from using unusual methanogen electron donors such as coenzyme F420 (8-hydroxy-5-deazaflavin) [1] to accept electrons from the more common electron donors of bacteria. In methanogens, the DmrX protein contains FMN and two iron-sulfur clusters that render the protein sensitive to inactivation by $\mathrm{O}_{2}$. In contrast, the bacterial homolog DmrB contains FMN but lacks iron-sulfur clusters. Although DTT has been previously shown reduce the iron-sulfur flavoprotein DmrX [10], the current work has demonstrated that DTT could not reduce FMN in the aerobic bacterial homolog DmrB (Figure 2). The inability of DTT to reduce the FMN of DmrB may have resulted from loss of the $\mathrm{O}_{2}$-sensitive $4 \mathrm{Fe}-4 \mathrm{~S}$ clusters in the bacterial homolog as a consequence of horizontal gene transfer from strictly anaerobic archaea to bacteria. Consistent with this hypothesis is the observation that when DmrX is exposed to air, DTT can no longer function as an electron donor in the assay (S. Wang and M. Rasche, unpublished results). From an evolutionary standpoint, the loss of the iron-sulfur clusters in DmrB may have been necessary to accommodate bacterial cofactors rather than uncommon archaeal redox agents such as coenzyme $\mathrm{F} 420$, which replaces $\mathrm{NAD}(\mathrm{P}) \mathrm{H}$ in some hydride transfer reactions [1]. Evolutionary adaptation of redox enzymes to bacterial cofactors has been observed previously in the a-proteobacterium $M$. extorquens, where two oxidoreductases involved in $\mathrm{H}_{4}$ MPT-linked metabolism, methylene tetrahydromethanopterin dehydrogenase [23] and dihydromethanopterin reductase A [24] [25], do not resemble archaeal enzymes; instead, they resemble the $\mathrm{NAD}(\mathrm{P}) \mathrm{H}$-dependent 
bacterial enzymes methylene tetrahydrofolate dehydrogenase and dihydrofolate reductase, respectively.

$\mathrm{CO} / \mathrm{CODH} /$ ferredoxin has been proposed as a physiological electron donor for both DmrX [10] and an archaeal flavoprotein homolog (AfpA) that lacks $4 \mathrm{Fe}-4 \mathrm{~S}$ clusters [11]. The current work demonstrates that archaeal CO/CODH/ferredoxin effectively reduces bacterial DmrB (Figure 4). A future assay for DmrB could be developed by combining $\mathrm{CO} / \mathrm{CODH} /$ ferredoxin with $\mathrm{DmrB}$ and the assay components for detecting the product $\left(\mathrm{H}_{4} \mathrm{MPT}\right)$, which is coupled to NADH production via methylene $\mathrm{H}_{4} \mathrm{MPT}$ dehydrogenase [11] [26]. However, a CODH-based assay would be complicated by the need to grow strictly anaerobic methanogens and use an $\mathrm{O}_{2}$-free chamber to purify $\mathrm{CODH}$ and ferredoxin, which are not commercially available.

An alternative electron donor system for $\mathrm{DmrB}$ has been proposed from a DmrB crystal structure in which two molecules of FMN (rather than one) were unexpectedly found per active site of DmrB [12]. The presence of an extra FMN in the structure led to a hypothetical ping-pong mechanism for electron transfer (Figure 1(b)) in which a tightly bound DmrB-FMN (FMN-1) receives electrons from a loosely bound $\mathrm{FMNH}_{2}$ molecule (reduced FMN-2), which could be re-reduced by a hypothetical $\mathrm{NAD}(\mathrm{P}) \mathrm{H}$-dependent flavin-reducing enzyme (Fre). In the current work, we tested the feasibility of this mechanism using Fre from $S$. enterica. NADH in combination with Fre successfully reduced the prosthetic group of DmrB (Figure 3), providing the first biochemical evidence for the feasibility of the ping-pong mechanism. Complete reduction using the NADH/Fre system took about an hour, and the initial velocity $(1.3 \mu \mathrm{M} / \mathrm{min})$ was more than an order of magnitude lower than the rate with the $\mathrm{CO} / \mathrm{CODH} /$ ferredoxin system (Figure 4), showing that the conditions might be further optimized in the future. Nevertheless, for reasons discussed above, if $\mathrm{DmrB}$ can be pre-reduced by incubating with NADH and Fre prior to mixing with the substrate, the creation of an $\mathrm{NADH} /$ Fre-based DmrB assay may be more convenient and less cumbersome than using $\mathrm{CO} / \mathrm{CODH} /$ ferredoxin as the electron donor.

With regard to the proposed DmrB ping-pong mechanism of electron transfer [12], it was unexpected to find that $\mathrm{DmrB}$ could be reduced by NADH and Fre alone without the need for added FMN. Since FMN-1 not covalently bound (12), it is possible that a small amount of FMN-1 may have diffused out of the DmrB active site and acted in the role of exogenous reduced FMN-2. Alternatively, the NADH/Fre system might be indeed be capable of facilitating the reduction of the DmrB prosthetic group without exogenous FMN. This would be similar to the activity of an E. coli flavoprotein reductase (Fpr) that directly reduces FMN-containing flavodoxins using electrons from NADPH [27]. Thus, Fre appears to reduce both exogenous FMN-2 and the FMN-1 prosthetic group of DmrB.

For the second $\mathrm{H}_{4} \mathrm{MPT}$ biosynthesis flavoprotein, MM1853 from the methanogen M. mazei, DTT was found to reduce the FMN prosthetic group within 30 
min (Figure 6). This was somewhat surprising since MM1853, like DmrB, lacks iron-sulfur clusters. Future computational analysis of the crystal structures of DmrB and MM1853 might provide clues about active site residues in MM1853 that could alter the redox properties of the FMN prosthetic group and contribute to its DTT-mediated reduction. Interestingly, the NADH/Fre system was also shown to fully reduce MM1853 within $5 \mathrm{~min}$ (Figure 7), which is faster than when DTT was used as the electron donor (Figure 6). This result could facilitate the development of a future enzyme assay to discover the function of MM1853 and raises the possibility that a similar Fre-type system may function in methanogenic archaea. Although it is possible that the physiological electron donor in methanogens may be CODH/ferredoxin, F420, or another uncommon methanogen coenzyme, these materials are not commercially available. Thus, the $\mathrm{NADH} /$ Fre system currently offers an advantage over other potential electron donors for the development of a new assay to probe the function of MM1853. Our current hypothesis is that MM1853 might contribute to the third reaction of $\mathrm{H}_{4}$ MPT side chain biosynthesis, which was previously proposed by White [7] to involve the reductive opening of a ribose ring to form the linear ribitol of $\mathrm{H}_{4} \mathrm{MPT}$, as illustrated in Figure 8 .

\section{Conclusion}

In conclusion, this work describes the discovery of electron donors for two previously uncharacterized flavoproteins involved in $\mathrm{H}_{4} \mathrm{MPT}$ biosynthesis. DmrB could be reduced by a $\mathrm{CO} / \mathrm{CODH} /$ ferredoxin and an NADH/Fre system, providing the first biochemical evidence supporting the proposed ping-pong mechanism

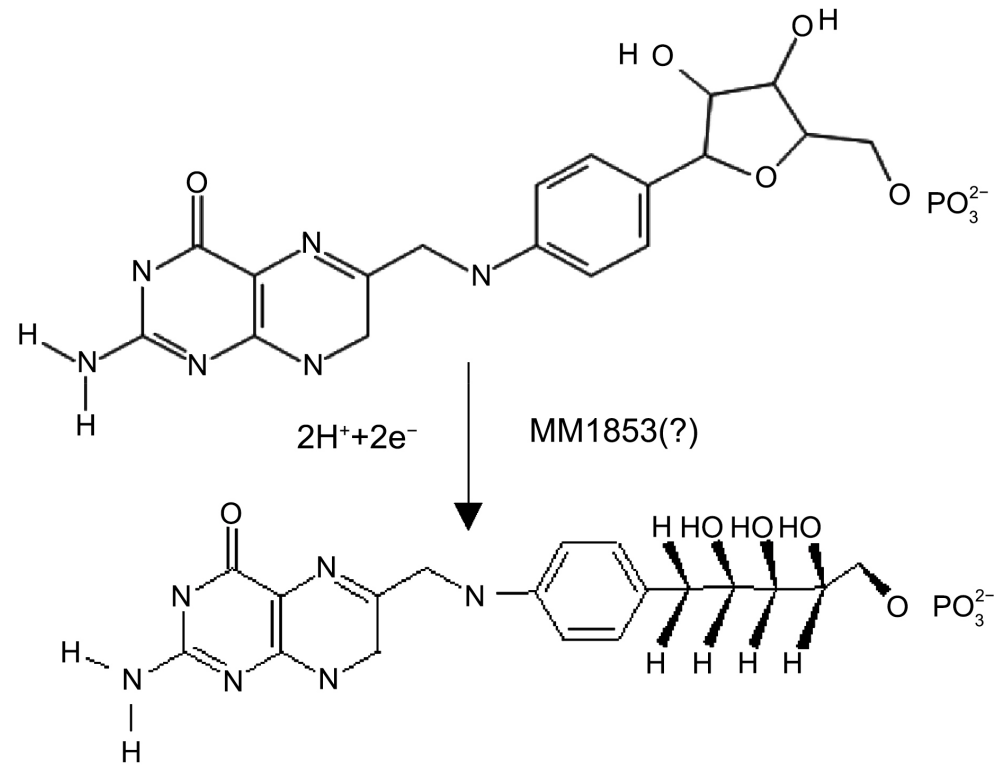

Figure 8. The flavoprotein MM1853 might potentially be involved in the third step of $\mathrm{H}_{4} \mathrm{MPT}$ side chain biosynthesis. As an oxidoreductase, one possible role for MM1853 could be in the reductive opening of the ribose ring to form the ribitol moiety of $\mathrm{H}_{4} \mathrm{MPT}$, as described by White [7]. 
of electron transfer [12]. Since $\mathrm{CODH}$ and ferredoxin are $\mathrm{O}_{2}$-sensitive and commercially unavailable, future studies will initially use NADH/Fre as an artificial electron donor system for DmrB. The finding that MM1853 could be reduced by DTT or the NADH/Fre system provides two possible electron donors that can be used in future studies to test the hypothesis that MM1853 catalyzes the third step of $\mathrm{H}_{4} \mathrm{MPT}$ side chain biosynthesis. Development of these two enzyme assays would provide tools for the discovery of novel inhibitors that could mitigate methane production as a greenhouse gas by methanogenic archaea.

\section{Acknowledgements}

This work was supported by National Science Foundation grant CHE-1508801 and a grant from the California State University Program for Education and Research in Biotechnology. The authors are grateful for the preliminary electron transfer work of Jose Martinez and Stephen Gonzalez with flavin-reducing enzyme (Fre).

\section{Conflicts of Interest}

The authors declare no conflicts of interest regarding the publication of this paper.

\section{References}

[1] DiMarco, A.A., Bobik, T.A. and Wolfe, R.S. (1990) Unusual Coenzymes of Methanogenesis. Annual Review of Biochemistry, 59, 355-394. https://doi.org/10.1146/annurev.bi.59.070190.002035

[2] Escalante-Semerena, J., Rinehart, K. and Wolfe, R. (1984) Tetrahydromethanopterin, a Carbon Carrier in Methanogenesis. Journal of Bacteriology, 259, 9447-9455.

[3] Dumitru, R., Palencia, H., Schroeder, S.D., DeMontigny, B.A., Takacs, J.M., Rasche, M.E., Miner, J.L. and Ragsdale, S.W. (2003) Targeting Methanopterin Biosynthesis to Inhibit Methanogenesis. Applied and Environmental Microbiology, 69, 7236-7241. https://doi.org/10.1128/AEM.69.12.7236-7241.2003

[4] Chen. D. (2013) Introduction. Climate Change. In: Stocker, T.F., Qin, D., Plattner, G.-K., Tignor, M., Allen, S.K., Boschung, J., Nauels, A., Xia, Y., Bex, V. and Midgley, P.M., Eds., Climate Change 2013: The Physical Science Basis. Contribution of Working Group I to the Fifth Assessment Report of the Intergovernmental Panel on Climate Change, Cambridge University Press, Cambridge, UK, 123-155.

[5] Yan, X., Hiroko, A., Kazuyuki, Y. and Hajime, A. (2009) Global Estimations of the Inventory and Mitigation Potential of Methane Emissions from Rice Cultivation Conducted Using the 2006 Intergovernmental Panel on Climate Change Guidelines. Global Biogeochemical Cycles, 23, GB2002. https://doi.org/10.1029/2008GB003299

[6] Samuel, B.S., Hansen, E.E., Manchester, J.K. Coutinho, P.M., Henrissat, B., Fulton, R., Latreille, P., et al. (2007) Genomic and Metabolic Adaptations of Methanobrevibacter smithii to the Human Gut. Proceedings of the National Academy of Sciences of the United States of America, 104, 10643-10648. https://doi.org/10.1073/pnas.0704189104

[7] White, R.H. (1996) Biosynthesis of Methanopterin. Biochemistry, 35, 3447-3456. https://doi.org/10.1021/bi952308m 
[8] White, R.H. (1998) Methanopterin Biosynthesis, Methylation of the Biosynthetic Intermediates. Biochimica et Biophysica Acta, 1380, 257-267. https://doi.org/10.1016/S0304-4165(97)00148-7

[9] Kalyuzhnaya, M.G., Korotkova, N., Crowther, G., Marx, C.J., Lidstrom, M.E. and Chistoserdova, L. (2005) Analysis of Gene Islands Involved in Methanopterin-Linked $\mathrm{C}_{1}$ Transfer Reactions Reveals New Functions and Provides Evolutionary Insights. Journal of Bacteriology, 187, 4607-4614. https://doi.org/10.1128/JB.187.13.4607-4614.2005

[10] Wang, S., Tiongson, J. and Rasche, M.E. (2014) Discovery and Characterization of the First Archaeal Dihydromethanopterin Reductase (DmrX), an Iron-Sulfur Flavoprotein from Methanosarcina mazei. Journal of Bacteriology, 196, 203-209. https://doi.org/10.1128/JB.00457-13

[11] Ding, Y.H.R. and Ferry, J.G. (2004) Flavin Mononucleotide-Binding Flavoprotein Family in the Domain Archaea. Journal of Bacteriology, 186, 90-97. https://doi.org/10.1128/JB.186.1.90-97.2004

[12] McNamara, D.E., Cascio, D., Jorda, J., Bustos, C., Wang, T.C., Rasche, M.E., Yeates, T.O. and Bobik, T.A. (2014) Structure of Dihydromethanopterin Reductase, a Cubic Protein Cage for Redox Transfer. Journal of Biological Chemistry, 289, 8852-8864. https://doi.org/10.1074/jbc.M113.522342

[13] Chistoserdova, L., Rasche, M.E. and Lidstrom, M. (2005) Novel Dephospho-Tetrahydromethanopterin Biosynthesis Genes Discovered via Mutagenesis in Methylobacterium extorquens AM1. Journal of Bacteriology, 187, 2508-2512. https://doi.org/10.1128/JB.187.7.2508-2512.2005

[14] Fonseca, M.V. and Escalante-Semerena, J.C. (2000) Reduction of Cob(III)alamin to Cob(II)alamin in Salmonella enterica Serovar Typhimurium LT2. Journal of Bacteriology, 182, 4303-4309. https://doi.org/10.1128/JB.182.15.4304-4309.2000

[15] Spyrou, G.E., Haggard, L., Krook, M., Jornvall, H., Nilsson, E. and Reichard, P. (1991) Characterization of the Flavin Reductase Gene (Fre) of Escherichia coli and Construction of a Plasmid for Overproduction of the Enzyme. Journal of Bacteriology, 173, 3673-3679. https://doi.org/10.1128/JB.173.12.3673-3679.1991

[16] Fieschi, F., Nivière, V., Frier, C., Décout, J.L. and Fontecave, M. (1995) The Mechanism and Substrate Specificity of the NADPH, Flavin Oxidoreductase from Escherichia coli. The Journal of Biological Chemistry, 270, 30392-30400. https://doi.org/10.1074/jbc.270.51.30392

[17] Terlesky, K.C., Nelson, M.J. and Ferry, J.G. (1986) Isolation of an Enzyme Complex with Carbon Monoxide Dehydrogenase Activity Containing Corrinoid and Nickel from Acetate-grown Methanosarcina thermophila. Journal of Bacteriology, 168, 1053-1058. https://doi.org/10.1128/JB.168.3.1053-1058.1986

[18] Macheroux, P. (1999) UV-Visible Spectroscopy as a Tool to Study Flavoproteins. Methods in Molecular Biology, 131, 1-7. https://doi.org/10.1385/1-59259-266-X:1

[19] Bradford, M.M. (1976) A Rapid and Sensitive Method for the Quantitation of Microgram Quantities of Protein Utilizing the Principle of Protein-Dye Binding. Analytical Biochemistry, 72, 248-254. https://doi.org/10.1016/0003-2697(76)90527-3

[20] Garfin, D. (1990) One-Dimensional Gel Electrophoresis. Methods in Enzymology, 182, 425-441. https://doi.org/10.1016/0076-6879(90)82035-Z

[21] Kopecný, J., Jurčuk, J.F. and Bartoš, S. (1983) The Effect of pH and 1,4-Dithiothreitol on the Adhesion of Rumen Bacteria. Folia Microbiologica Praha, 28, 130-133.

https://doi.org/10.1007/BF02877369 
[22] Sperker, S., Gsaller, G., Marek, H. and Gritzner, G. (1988) Solvent Properties of Ethanediol and 2-Mercaptoethanol. Journal of Solution Chemistry, 17, 35-46. https://doi.org/10.1007/BF00651851

[23] Hagemeier, C.H., Chistoserdova, L., Lidstrom, M.E., Thauer, R.K. and Vorholt, J.A. (2000) Characterization of a Second Methylene Tetrahydromethanopterin Dehydrogenase from Methylobacterium extorquens AM1. European Journal of Biochemistry, 267, 3762-3769. https://doi.org/10.1046/j.1432-1327.2000.01413.x

[24] Marx, C.J., O’Brien, B.N., Breezee, J. and Lidstrom, M.E. (2003) Novel Methylotrophy Genes of Methylobacterium extorquens AM1 Identified by Using Transposon Mutagenesis Including a Putative Dihydromethanopterin Reductase. Journal of Bacteriology, 185, 669-673. https://doi.org/10.1128/JB.185.2.669-673.2003

[25] Caccamo, M.A., Malone, C.S. and Rasche, M.E. (2004) Biochemical Characterization of Dihydromethanopterin Reductase, a Tetrahydromethanopterin Biosynthesis Enzyme in Methylobacterium extorquens AM1. Journal of Bacteriology, 186, 2068-2073. https://doi.org/10.1128/JB.186.7.2068-2073.2004

[26] Rasche, M.E., Havemann, S.A. and Rosenzvaig, M. (2004) Characterization of Two Methanopterin Biosynthesis Mutants of Methylobacterium extorquens by Use of a Tetrahydromethanopterin Bioassay. Journal of Bacteriology, 186, 1565-1570. https://doi.org/10.1128/JB.186.5.1565-1570.2004

[27] Jenkins, C.M. and Waterman, M.R. (1998) NADPH-Flavodoxin Reductase and Flavodoxin from Escherichia coli: Characteristics as a Soluble Microsomal P450 Reductase. Biochemistry, 37, 6106-6113. https://doi.org/10.1021/bi973076p 